\title{
Pedagogical Knowledge for Teaching Mathematics in Montessori Schools
}

\author{
Immaculate Kizito Namukasa ${ }^{1^{*}}$ (D), Kinful Lartebea Aryee ${ }^{1}$ (D)
}

${ }^{1}$ University of Western Ontario, CANADA
${ }^{\star}$ Corresponding Author: inamukas@uwo.c

Citation: Namukasa, I. K., \& Aryee, K. L. (2021). Pedagogical Knowledge for Teaching Mathematics in Montessori Schools. International Electronic Journal of Mathematics Education, 16(3), em0646. https://doi.org/10.29333/iejme/11005

\begin{tabular}{|c|c|}
\hline ARTICLE INFO & ABSTRACT \\
\hline Received: 14 Nov. 2020 & Teacher knowledge needed for teaching is widely studied to characterize its key categories. We report findings \\
\hline Accepted: 9 Jan. 2021 & $\begin{array}{l}\text { from a study on teachers' knowledge for mathematics in the Montessori schools. In Montessoriaccredited schools, } \\
\text { teachers learn to teach mathematics in ways different from the teachers themselves experienced in non- } \\
\text { Montessori schools. We ask: What knowledge do teachers learn? and how do they continue to refine this } \\
\text { knowledge in teaching in classrooms? We draw from a teacher knowledge framework based on cross-national } \\
\text { studies to interpret mixed data from a case study. We aim to inform research on teacher characteristics needed } \\
\text { for consistent implementation of instructional reform. Major findings from this study are that for K-6 Montessori } \\
\text { teachers to thrive in teaching mathematics in Montessori classrooms, they need teacher knowledge on Montessori } \\
\text { materials, on lesson and the presentation of content according to Montessori's philosophy and pedagogy; as well } \\
\text { as on the process of independently understanding concepts to be presented. The findings contribute to further } \\
\text { theorizing on teacher knowledge which has implications is designed to teacher training opportunities in three } \\
\text { subcategories; namely teaching, learning, and professional competence knowledge. }\end{array}$ \\
\hline
\end{tabular}

Keywords: mathematics teacher knowledge, instructional reform, pedagogical practices, classroom practices, learning materials, Montessori teaching, teacher professional competencies, mathematics content knowledge

\section{INTRODUCTION}

Teacher knowledge needed to teach mathematics has been studied within and across nations to characterize its categories. The question at the heart of both national and cross-national studies is on the knowledge needed to teach high quality and demanding curricular, such as reform curricular (e.g., Bagby \& Sulak, 2009; Clarke, Goos, \& Morony, 2007; Lang \& Namukasa, 2011).

Several studies (see e.g., Battey \& Franke, 2008; Price \& Ball, 1997) review and distinguish between "conventional" and "reform mathematics" teaching. "Reform raises questions about the core beliefs of mathematics education, moving to restructure thinking about the nature of mathematics, how it is taught, how it is learned, and, ultimately, what constitutes success in learning it" (Ellis \& Berry III, 2005, p. 8). Studies on reform practices agree on the following: Several reforms have been attempted over the years for many countries, however, in many countries, including Canada, reform has been slow or even missing out (Ashraf, 2019; Ellis \& Berry III, 2005) with renewed momentum in the 1980s (Eacott \& Holmes, 2010; Herrera \& Owens, 2001; Manouchehri \& Goodman, 1998).

Critics of reform have doubted if it is possible to implement curriculum and pedagogical reform in complex education settings (Eacott \& Holmes, 2010). According to Sztajn (1995), for instance, pedagogical reform based on Colburn's ideas was heavily criticized and discontinued before it reached the classroom teacher. Ross, McDougall, and Hogaboam-Gray (2002) observed that new math reform of the 1950-1960s failed miserably, because teachers were expected to develop pedagogical practices and materials with little or no training related to the reform ideas. Reform on pedagogical practices has been noted to focus on different practices, including content, tool, experience, problem solving, multi-representation, questioning, and discourse-based practices.

However, only few teachers implement more than one reform-based practices in their teaching (Drake, 2006). Further, teachers' interpretations of selected reform practice may vary (Manouchehri \& Goodman, 1998). Both teachers' knowledge and affective characteristics have been noted to play a role in implementing reform. Li and $\mathrm{Ni}$ (2011) noted that discourse-based reform practices were not implemented to match the content-based reform which the teachers were practicing. The question at the heart of mathematics education reform research is, how might teacher education programs prepare and support teachers to interpret and implement coherent pedagogical reform practices in their classrooms? 
The Context: A few studies, such as Livstrom, Szostkowski, and Roehrig (2019), look outside traditional school settings to study pedagogical practices. Accredited private/independent schools are a unique case for studying teacher knowledge needed to implement non-conventional pedagogical practices. Teachers in accredited private education systems are expected to consistently teach their mandated curriculum using specific materials and pedagogies (Davenport, 2000; Marshall, 2017), and to assess students in ways aligned to the system's philosophy. Maria Montessori (1870-1952)'s published curriculum together with its supporting resources and learning materials, which were widely researched and widely published on her work in the $1920 \mathrm{~s}$, continue to be researched and developed independently and by Montessori organizations in different countries (see e.g., Lillard \& Else-Quest, 2006). According to Lillard (2005), the provision of a detailed curriculum and resources in the Montessori system is a key factor in the interpretation and implementation of Montessori teaching practices. Meanwhile, Montessori system, as Lillard (2019) indicated "is still marginalized in discussions of education reform" (p. 940).

Whitescarver and Cossentino (2006), Jamilah (2018), and Lillard (2019) observed that there are at least 22,000 Montessori schools in more than 100 countries in the world. In certain countries Montessori schools are public-funded. In the Canadian province of Ontario, where the study took places, of the over 1401 private and non-government funded schools, 112 private schools considered themselves Montessori schools. Fifty of these Montessori schools had membership with a national or international Montessori society. Only seven of the Montessori schools offered credits towards the Ontario Secondary School Diploma program.

The Challenge: Many studies on mathematics teacher education, including the Teacher Education and Development Study in Mathematics (TEDS-M) have focused on investigating schools teaching programmatic curricular designed by ministries of education (Ingvarson et al., 2013). Teachers in alternative education systems who are not alumni of these systems need to learn to teach a different curricular other than they were taught when they went to school (Laski, Vasilyeva, \& Schiffman, 2016). The case is the same with teachers in publicly-funded schools when implementing mathematics teaching, curriculum or assessment reform in education. Our study investigated the knowledge characteristics of teachers-what teacher knowledge was needed and what competencies were needed by teachers in the Montessori education system?

Research questions: The specific research questions are: (1) What knowledge do Montessori teachers need and learn? (2) How do these teachers continue to refine this knowledge in classroom practices?

Need and Significance: Studies currently investigate different aspects of the Montessori education system in comparison with other school systems. Most studies on the Montessori education system focus on general classroom practices (Cossentino, 2006; Namukasa, 2016) and general teacher education (Beatty, 2011) at specific levels of their education systems. The few studies that focus on the teaching and learning of mathematics have further been narrowed to focus on investigating learning of specified concepts such as number sense concept (Litster, Moyer-Packenham, \& Reeder, 2019; Mix et al., 2017; Peng \& Md-yunus, 2014). Other studies compare Montessori students' performance to the performance of students of other education systems on mathematics tests (Peng \& Md-yunus, 2014). Few studies-such as Chipangura and Aldridge (2017) and Faryadi (2017) -focus on Montessori mathematics teacher knowledge.

This study also responds to the needs identified in the literature on mathematics knowledge, particularly on preparing and supporting teachers when adopting specific reform teaching practices. It identifies sites where content knowledge for teaching in a specific education system is learned (Ball, 2002; Ball, Lubienski, \& Mewborn, 2001), connected to lessons taught by teachers (Clarke et al., 2007), and how this knowledge is further influenced by classroom practice (Ponte \& Chapman, 2006). Findings from this study promise to inform mathematics teacher learning, practices, and instructional reform.

\section{RELATED LITERATURE}

This study is informed mainly by three literatures on Montessori education: Montessori education philosophy and learning environment, Montessori curriculum and teaching approach; and Montessori learning materials and activities literature which we review in the next section.

\section{Montessori Education Philosophy}

Several of the reforms practiced in Montessori schools have been noted to have similarities with the instructional reforms advanced by Jerome Bruner, Warren Colburn, Jean Piaget and influenced by J. H. Pestalozzi (Cossentino, 2005; Ervin, Wash, \& Mecca, 2010). Lillard and Else-Quest (2006), for instance, compared the Montessori education system to mainstream reform and noted relations between Montessori teaching practices and the instructional reform in the mainstream schools. According to Lopata, Wallace, and Finn (2005), Montessori education was initially developed by Maria Montessori in 1907 to serve children who were economically disadvantaged "however, this education has become well known in affluent communities" (p. 5).

In the Montessori approach to education and teaching practices, learners work independently on manipulative materials, and on practical life activities (Elkin, Sullivan \& Bers, 2014; Lillard, 2012; Saracho \& Spodek, 2009). Learners in the classrooms according to Cossentino (2006), Faryadi (2007), and Lillard, (2007, 2013) - are mostly guided by the teacher to construct their own learning through interactions with concrete materials. Lillard (2013) added that classroom settings may comprise age groupings ranging three years- "infant to three years old, three to six, six to nine, and nine to twelve" (p. 3).

Moreover, unlike public funded schools whereby the teachers and learners are usually assigned sitting places and with teachers controlling material usage, the pedagogical approach and teaching and learning content, Barbieru (2016), Kayili and Ari (2011), and Lillard (2018) noted that in Montessori education system, learners, in individual and small group settings, are able to select their own workstations in the classroom without any restrictions and they select what to learn for the day. Barbieru (2016), 
Lillard (2012), and Lillard and Heise (2016) indicated that children, therefore, have opportunities to make certain choices on several aspects of their learning, such as selection of materials, content and pedagogy. Kayili and Ari (2011) added that this approach to teaching is constructed on the child's interest whereby children have the freedom to select what to learn, where to learn and how to learn with the teacher just serving as a guide. Lillard (2019) explained that allowing children the space to develop themselves in this manner helps them to be independent.

According to Kayili and Ari (2011), and Lillard (2019), the fundamental philosophy behind Montessori education is for the child to be a self-reliant, independent learner through a wholistic and cosmic education approach. Raimondo (2018) viewed cosmic education as children performing activities and learning in an orderly manner in order to understand their world and become independent learners. Features such as observation, child centered activities, and creating a conducive learning environment were important in teaching as well as assisting learners to become self-reliant (Ross, 2012). According to Ross, education as indicated by Maria Montessori is "not acquired by [the] child listening to words, but in virtue of experiences in which the child acts on his environment." (p. 101) Saracho and Spodek (2009) noted that almost everything in the world revolves around mathematics, so is Montessori educational approach; its teaching revolves around mathematics.

To promote such education, Kayili and Ari suggested the need to provide learners with fundamental features of Montessori education such as a well-prepared learning environment (Spodek \& Saracho, 2009), appropriate learning materials (Lillard, 2018), and support them to be independent learners and self-reliant through Montessori's unique content and curriculum, teaching method, learning materials, method of assessment and classroom set-up. This form of educational approach, according to Kayili (2011), would allow children to effectively interact with concrete materials in their environment, understand mathematical skills (Reed, 2016), and develop their own knowledge by acquiring mathematical skills such as geometric thinking (Toran, 2011). When it comes to mode of assessment of learners' achievements, in Montessori education teachers observe children as they work in their classroom environment, review children's self-created portfolios and rarely view assessment of students to be based on instruments such as tests and grades (Christle, 2010).

In the same way, other researches (see for example, Bagby \& Sulak, 2010; Cossentino, 2005; Shiraz \& Quisar, 2017) compared pedagogical practices of the Montessori systems to public schooling systems and noted relations to learning theories in Montessori education that focus on constructivism (Bagby \& Sulak, 2010), playful and mindful learning (Lillard, 2007, 2013), student motivation (Rathunde \& Csikszentmihalyi, 2005) and development of executive and transferrable skills among learners (Franczak, 2016). In line with the above learning theories, Cossentino (2009), and Beatty's (2011) research studies focus on teacher education, whereas Faryadi (2017), and Laski et al. (2016) focus specifically on Montessori mathematics education with emphasis on pedagogies that would aid learners' understanding and construction of their own learning.

In the next subsections, we elaborate on specific key tenets which distinguish the Montessori curricular from public curricular (Cossentino 2005; Rosanova, 2003).

\section{Montessori Mathematics and Teaching Approach}

A teacher's knowledge, beliefs and attitudes toward teaching and learning are believed to interact in many ways with their teaching methods in an ecosystem of curriculum, and learning philosophies (Guerriero, 2014; Kutaka et al., 2017; Sewornoo, 2016; Shiraz \& Quisar, 2017). In the same way, Kuennen and Beam (2020) noted that teaching content in a classroom starts with a problem task that needs to be designed and solved. The teacher acts as a guide and supports children to construct their own learning in the classroom by performing several activities through hands-on, child-centered activities (Lillard, 2011; Thayer-Bacon, 2012).

In regard to the teaching approach, Kayili and Ari (2011) conducted a study on effects of Montessori teaching approach on preschoolers' readiness for primary school in terms of their number sense, social readiness and concentration skills, and found that teachers' method of teaching played a significant role in their learners' transitions as compared with government funded schools. This result is not different from what Lillard (2019) noted from her studies at the Montessori school with kindergarten learners in terms of their performance in both academic achievement and social cognition.

For Montessori teaching approach to continue to be effective for both the learner and the educator, Lillard and Heise (2016) suggested the need for classrooms to embrace certain features and practices such as designing classrooms to fit the needs and interest of the child. Design would include a well-prepared learning environment, accessibility to appropriate learning materials, maintaining learners' interest in their learning by teachers serving as guides and only to interrupt when needed. Faryadi (2007) added that although learners' needs and interests take priority when it comes to Montessori education, in order to view this form of education as authentic, children's learning approach needs to be prescribed with little or no modification from the original Maria Montessori's writings and philosophy.

According to Lillard (2005), the prescribed learning approach involves offering teachers with a detailed curricular to teach as well as supporting resources for teaching the curricular. The supporting materials according to Cossentino (2005) include Montessori teaching materials, and detailed guidance on how to organize the materials and the learning environment.

In addition, teachers are provided with a series of scripted lesson presentations and activities (Beatty, 2011) and are instructed to be mindful of all their interaction as adults in the classroom (Belova, Eilks, \& Feierabend, 2015; Faryadi, 2017). More so, Bagby and Sulak (2010), and Lillard and Else-Quest (2006) describe this learning approach to involve teachers teaching children by providing them opportunities to interact with concrete materials in multi-grade classrooms of two 2-3-hour lesson blocks a day. To Barbieru (2016), teaching children in a multi-grade classroom offers younger learners' chances to interact and "imitate the work" of older learners around them. 
Barbieru (2016) noted that the Montessori method of teaching may be viewed by other researchers as having passive educators with learners doing the work by themselves as compared with the traditional classroom whereby learners "passively receiving information" from teachers (p. 109). To respond to these critics, Barbieru (2016) explained that prior to learners working on their own, Montessori teachers would first introduce the lesson including needed materials to them to get an idea, after which teachers slowly withdraw from the environment and take the role of observers and guides. For the Montessori teaching method to be effective and for teachers to successfully follow prescribed teaching and learning approaches, Barbieru and Lillard (2019) suggested educators undergo some form of training to understand various teaching aspects, such as prepared learning environment, materials' usage, content and presentations.

Further, Cossentino (2005) added that the strict adherence to the provided lessons and their presentations helps to promote productive learning skills.

\section{Montessori Learning Materials and Activities}

Ryniker and Shoho (2001) indicated that Montessori's method of teaching is based on the idea that children learn through exploration. Learning is not only about listening; it encompasses varieties of activities. According to Ross (2012), learning is defined as "a natural process, the necessity of spontaneous activity, a prepared environment, and the transformation of the teacher from a classroom star to an actor in a supporting role" (p. 93). Teachers provide structure in the classroom "by guiding the children's learning towards established goals" (Lillard, 2013, p. 142). Further, the Montessori approach to learning according to Lillard (2018), Ross (2012), and Spodek and Saracho (2009), is child-centered and involves children independently working with real and attractive materials, which are placed in the classroom environment and introduced to children to interact with and imitate the adult/teachers' actions that portray real life situations.

Lillard (2019) noted that in a Montessori learning environment, having prepared and organized environment to support sensorial education whereby children are able to engage with manipulable materials. Certain Montessori materials are "key to the world that the primary materials present" (Lillard, 2011, p. 20), and the essence teaching of a specific concept (Kuennen \& Beam, 2020), or assisting children develop certain learning skills, such as how to write and then read, and how to do mathematics and geometry. For instance, Lillard (2019) mentioned that teachers are able to select specific materials, including sensory, language, and mathematics materials (Lillard, 2013, 2019), and organize and store the materials in a classroom in such a way that learners could easily identify and access them (Kayili \& Ari, 2011).

The importance of Montessori materials is supported by experimental studies (see for example, Lillard, 2012, 2019; Lillard \& Heise, 2016) which showed that Montessori children who learn mainly with Montessori materials tend to perform better than those learning with non-Montessori materials. Further, Rule and Stewart (2002) noted that materials that involved preschool children performing activities resulted in the development of finer motor skills improvement as compared with children in classrooms without these materials and activities. Kuennen and Beam (2020) added that the selection, use and performance of several activities with the learning materials is effective at in promoting children's understanding in and developing a sense of competence.

Use of materials is noted to also benefit the development of learning characteristics including: student self-determination" features (Lillard, 2019, p. 944 ), correcting own learning mistakes with little teacher intervention (Barbieru, 2016; Kayili \& Ari, 2011), social and emotional skills (Sawyer, 2001); self-discipline, self-control through their work (Lillard, 2013, 2019; Thayer-Bacon, 2012), developing independency and learning in a more "self-sufficient way" (Spodek \& Saracho, 2009, p. 308). In sum, providing children the opportunity to learn on their own through guided interaction with the materials and manipulatives in order to satisfy their "basic human needs according to the self-determination theory" is what the Montessori system and philosophy is all about (Lillard, 2019, p. 956).

However, Thayer-Bacon (2012), noted that some teacher-education students - in a manner, similar to certain researchers (see for example, Debs 2019; Diamond \& Lee 2011; Elkind 2008; as noted by Lillard, 2013) - considered the activities children perform in Montessori schools "as play instead of work, and the didactic materials in the classroom is ... as noneducational" playful learning with no formal structure (Thayer-Bacon, 2012 p. 12). Lillard (2013) on the other hand, argued that Montessori classrooms may be viewed as unstructured and playful learning environment because children are offered the choice of materials to learn with. Thayer-Bacon (2012) added that the unstructured Montessori classrooms are "full of educational materials, so there is no 'bad choice' available for the students" (p. 13).

Despite the arguments, Lillard (2007), and Cossenito (2005) themselves, still raise questions on the extensive use, limited selection per age band, limited student choice and customization, and the pre-specified usage of materials. In terms of materials, for instance, Lillard (2011) noted from one of her studies regarding their status in Montessori classrooms and indicated that although there were several and desirable materials. However, not all of them are essential for learners.

In the next section, we elaborate on the analytical framework we adopt for studying teacher knowledge and affective responses.

\section{FRAMEWORK}

Our work on teacher knowledge characteristics is framed by categories noted in the literature on the nature of knowledge required for teaching school mathematics. Canãdas et al. (2013), following TEDS-M, considered four major categories of content knowledge and pedagogy knowledge that should be taught to teachers in teacher preparation programs: school mathematics content knowledge, tertiary mathematics content knowledge, mathematics pedagogy and general pedagogy. Tatto (2013), and 
Tatto and Senk (2011) identify the following more detailed categories: Mathematics content knowledge (MCK)-school and tertiary, mathematics education, general education pedagogy, teaching for diversity, reflection on practice, school experiences and the field experience, as well as coherence of the teacher education program. Blömeke (2014), NCTM (2012), Wang and Tang (2013), Burton (2003), and Monroe (1984) offer additional categories. We summarize the categories as a conceptual framework in Table 1. These categories include: Teacher knowledge of Teaching, of Curriculum, of Learning, of Contexts, of Affective responses, Professional knowledge, and knowledge gained through Field Experiences and Clinical Practice. Because our study was carried out with in-service teachers, we leave out the field and clinical practice category that describes an avenue of teacher learning.

Table 1. A Classification of Knowledge for Teaching Mathematics

\begin{tabular}{|c|c|c|c|c|c|}
\hline Knowledge Category & $\begin{array}{l}\text { TEDS-M subcategories, } \\
\text { topics, activities, \& } \\
\text { experiences (Tatto, 2013). }\end{array}$ & $\begin{array}{l}\text { Wang \& Tang } \\
(2013)\end{array}$ & $\begin{array}{l}\text { Blömeke } \\
(2014)\end{array}$ & NCTM (2012) & Our Study \\
\hline $\begin{array}{l}\text { Teaching issues } \\
\text { (e.g., planning, } \\
\text { reflection, and } \\
\text { foundations of } \\
\text { mathematics) }\end{array}$ & $\begin{array}{l}\text { Planning for mathematics } \\
\text { teaching and learning } \\
\text { Mathematics instruction } \\
\text { Developing teaching plans, } \\
\text { observing, analyzing and } \\
\text { reflecting on mathematics } \\
\text { teaching }\end{array}$ & $\begin{array}{l}\text { Mathematics } \\
\text { teaching issues } \\
\text { (including } \\
\text { curriculum/ } \\
\text { content } \\
\text { standards) }\end{array}$ & $\begin{array}{l}\text { Teacher } \\
\text { learning }\end{array}$ & Content Pedagogy & $\begin{array}{l}\text { Mathematics teaching } \\
\text { environment } \\
\text { Mathematics teaching issues } \\
\text { (including selecting } \\
\text { appropriate teaching } \\
\text { materials) }\end{array}$ \\
\hline $\begin{array}{l}\text { Curriculum } \\
\text { (e.g., school content } \\
\text { and assessment) }\end{array}$ & $\begin{array}{l}\text { Curricular knowledge } \\
\text { (including foundations of } \\
\text { mathematics) } \\
\text { Mathematics standards and } \\
\text { curriculum }\end{array}$ & & & $\begin{array}{l}\text { Content Knowledge } \\
\text { Mathematical } \\
\text { Practices }\end{array}$ & $\begin{array}{l}\text { Curricula knowledge } \\
\text { (including material and tool- } \\
\text { based curriculum }\end{array}$ \\
\hline $\begin{array}{l}\text { Learning issues } \\
\text { (e.g., development of } \\
\text { mathematics thinking, } \\
\text { planning) }\end{array}$ & $\begin{array}{l}\text { Enacting mathematics for } \\
\text { teaching and learning } \\
\text { Development of } \\
\text { mathematics ability and } \\
\text { thinking } \\
\text { Learning activities engaged } \\
\text { in }\end{array}$ & $\begin{array}{l}\text { Mathematics } \\
\text { learning issues }\end{array}$ & $\begin{array}{l}\text { Pedagogical } \\
\text { practices }\end{array}$ & $\begin{array}{l}\text { Mathematical } \\
\text { learning Environment } \\
\text { including (e.g., } \\
\text { mathematics-specific } \\
\text { technology) } \\
\text { Influences on student } \\
\text { Learning }\end{array}$ & $\begin{array}{l}\text { Mathematical learning } \\
\text { environment (organized } \\
\text { materials) }\end{array}$ \\
\hline $\begin{array}{l}\text { Contexts } \\
\text { (e.g., equity and } \\
\text { diversity) }\end{array}$ & $\begin{array}{l}\text { Contexts of mathematics } \\
\text { education }\end{array}$ & $\begin{array}{l}\text { Contexts of } \\
\text { mathematics } \\
\text { education }\end{array}$ & $\begin{array}{l}\text { Context } \\
\text { knowledge }\end{array}$ & & \\
\hline $\begin{array}{l}\text { Affective issues } \\
\text { (e.g., motivational } \\
\text { issues and beliefs) }\end{array}$ & $\begin{array}{l}\text { Affective issues in } \\
\text { mathematics }\end{array}$ & $\begin{array}{l}\text { Affective issues in } \\
\text { mathematics }\end{array}$ & $\begin{array}{l}\text { Affective- } \\
\text { motivational } \\
\text { factors }\end{array}$ & & \\
\hline $\begin{array}{l}\text { Professional } \\
\text { competencies } \\
\text { (e.g., teacher inquiry) }\end{array}$ & $\begin{array}{l}\text { Instructional activities } \\
\text { experienced }\end{array}$ & & $\begin{array}{l}\text { Professional } \\
\text { competences }\end{array}$ & $\begin{array}{l}\text { Professional } \\
\text { Knowledge and Skills }\end{array}$ & $\begin{array}{l}\text { Professional knowledge } \\
\text { (including content } \\
\text { presentation) }\end{array}$ \\
\hline
\end{tabular}

\section{METHODS}

We carried out a case study of a Montessori school in Ontario, Canada. Browne (2005) explains that case study research methodology is based on the interpretive view of inquiry. Creswell (1998) and Merriam (1998, 2009) suggested that case study approach would be helpful when dealing with few cases. According to Patton (2002), the purpose of case study is to observe, organize, and analyse in-depth information, problems and relationships within a specific case of analysis. Nisbet and Watt (1994) defined case study as a "specific instance that is frequently designed to illustrate a more general principle" (p. 72). Cohen, Manion, and Morrison (2007) added that the single instance of a case study is of bounded system such as a classroom, a school or community. Robson (2002) also added that case studies opt for analytical rather than statistical generalization; that is, they develop a theory which can help researchers to understand other similar cases, phenomena or situations.

\section{Methods of Inquiry}

\section{Participants}

The research participants consisted of twelve K- 8 teachers with 5 to 25 plus years of teaching experience, who were working in an urban Montessori school in Ontario. Prior to conducting this study, we sought ethics approval from our university's ethics review board. A school administrator granted us access to solicit for study participants. Only the Grade 7 and 8 teachers specialized in teaching two or three other subjects, the rest taught several Montessori subjects including mathematics. All the participants were university graduates with teaching qualifications at the bachelors, graduate, postgraduate or Montessori teacher training (diploma) levels. Participants' Montessori training varied with many of them trained to teach in several levels (3 participants were trained to teach in one level, 4 in two levels, 3 in three levels and 1 in four levels). Only one participant was not trained in a Montessori teacher education institution and one participant was an alumnus of a Montessori school system. Two of the participants, T11 and T12, also had school administration experiences. Participants were also given an opportunity to consent to a selected data collection options of varying time commitments as shown in Tables 2 and 3. 
Table 2. Profile for Participants Teaching Preschool

\begin{tabular}{|c|c|c|c|c|c|}
\hline Participant & $\begin{array}{l}\text { Length of teaching/ } \\
\text { Admin experience }\end{array}$ & $\begin{array}{l}\text { Grade levels } \\
\text { taught }\end{array}$ & $\begin{array}{l}\text { Montessori teacher } \\
\text { training }\end{array}$ & Teaching Qualifications & Data Collected \\
\hline T01 & 23 & $\mathrm{Jk}-\mathrm{Sk}$ & yes & Preschool-Sk & $\begin{array}{l}\text { Long Questionnaire } \\
\text { Two interviews } \\
\text { Observations }\end{array}$ \\
\hline T02 & 14 & $\mathrm{Pk}, \mathrm{Jk}-\mathrm{Sk}$ & yes & Preschool & $\begin{array}{l}\text { Short Questionnaire } \\
\text { Two interviews } \\
\text { Observations }\end{array}$ \\
\hline$\overline{T 11}$ & 12 years & $\begin{array}{l}\text { Preschool } \\
\text { (Pk) (3-6) }\end{array}$ & yes & Preschool & $\begin{array}{l}\text { Short Questionnaire } \\
\text { One Interview } \\
\text { Teacher Manual }\end{array}$ \\
\hline
\end{tabular}

Table 3. Profile for Participants Teaching Grades 1-8

\begin{tabular}{|c|c|c|c|c|c|}
\hline Participant & $\begin{array}{l}\text { Length of teaching/ } \\
\text { Admin experience }\end{array}$ & $\begin{array}{l}\text { Grade levels } \\
\text { taught }\end{array}$ & $\begin{array}{l}\text { Montessori teacher } \\
\text { training }\end{array}$ & Teaching Qualifications & Data Collected \\
\hline T03 & 26 & $1-3$ & yes & $1-8$ & Long Questionnaire \\
\hline T04 & 15 & $1-3$ & yes & $1-3$ & Short Questionnaire \\
\hline T05 & 21 & $4-6$ & yes & $\mathrm{Jk}-8$ & $\begin{array}{l}\text { Long Questionnaire } \\
\text { Two interviews }\end{array}$ \\
\hline T06 & 13 & $4-6$ & yes & $1-6$ & $\begin{array}{l}\text { Short Questionnaire } \\
\text { Two interviews } \\
\text { Observations }\end{array}$ \\
\hline T07 & 18 & $4-6$ & yes & Pre- 6 & $\begin{array}{l}\text { Short Questionnaire } \\
\text { Two interviews } \\
\text { Observations }\end{array}$ \\
\hline T08 & 16 & 7,8 & no & $7-12$ & $\begin{array}{l}\text { Long Questionnaire } \\
\text { Two interviews }\end{array}$ \\
\hline T09 & 22 & 7,8 & yes & $1-3$ & $\begin{array}{l}\text { Long Questionnaire } \\
\text { One Interview }\end{array}$ \\
\hline T10 & 7 & 7,8 & yes & $4-10$ & $\begin{array}{l}\text { Long Questionnaire } \\
\text { No Interview }\end{array}$ \\
\hline T12 & 7 & $7,8\left(\& \mathrm{Pk}^{\star}\right)$ & yes & $4-10$ & $\begin{array}{l}\text { Long Questionnaire } \\
\text { One Interview }\end{array}$ \\
\hline
\end{tabular}

* Stands for previously taught

Jk - Sk Stands for Junior Kindergarten to Senior Kindergarten

For ethical purposes and given the small population of Montessori schools, participants were assigned numbers; and potentially identifying information such as gender was not reported.

\section{Data Collection and Procedures}

To obtain an understanding of teachers' knowledge in the Montessori school, mixed data were collected. Instruments for collecting data were: a written questionnaire-a short qualitative (4 pages) or a long mixed qualitative and quantitative form (10 pages)-completed at the start of the study; a semi-structured pre-observation interview and post-observation interview; observation (1 to 4 observations per grade-band); review of artefacts (notes, images and copies) provided by the participants; a focus group discussion at the end of the data collection period; and document analysis of the teachers' planning documents and instructional support materials. We used multiple methods of data collection, because past studies, such as Herrera and Owens (2001), on reform curriculum and practices have noted different results when only questionnaires are used than when used in combination with observation and interview instruments. The data were collected on teacher knowledge, affective characteristics, training experiences, and pedagogical practices.

\section{DATA ANALYSIS}

Survey data was first analyzed quantitatively. To begin with the analysis, responses on reverse items were straight-coded, responses duplicated on items checked to rule out guessing and neutral items noted for follow-up with a respective participant at a pre-observation interview. Then descriptive statistics on the factors were studied for consistence, contradiction, contrasts, similarities and correlations among the data. Disaggregated data was also studied by factors, question/item analyses and individual participants' profiles to explore further statistics of interest. Correlations among factors were studied.

Interview records were transcribed verbatim and data was organized and analyzed using both manual color coding-cuttingcollating as well as electronically using keyword-nodes-categories of nodes in NVivo software. Table 4 presents examples of the key words and nodes (responses to each interview question), category of nodes and then sub themes generated by analyzing transcript data. We further merged, re-organized and re-named the codes by having a team of researchers, including graduate student researchers and research associates, contribute to the analysis over a period prior to and after presenting the preliminary results to the participants. 
Table 4. Data Analyses and Themes

\begin{tabular}{|c|c|c|}
\hline Data Analyses & Teacher's Knowledge sample categories of nodes and codes & Teacher's Knowledge Themes \\
\hline Interview transcripts analysis. & Trained with \& know each material & Learning materials \\
\hline Descriptive analysis of survey data. & Purpose, method \& consistence & (a pre-existing theme in both the \\
\hline Corroborated with: & Concrete, sensorial and hands-on & questionnaire and interview data) \\
\hline \multirow{2}{*}{$\begin{array}{l}\text { Study of observation notes, pictures } \\
\text { and artefacts; }\end{array}$} & Stories of materials and real life & \\
\hline & Learn, play around with, present, lessons & Lesson presentations \\
\hline \multirow{2}{*}{$\begin{array}{l}\text { Document analysis of a manual, a } \\
\text { syllabus, lessons and activity excerpts; }\end{array}$} & Lessons as gifts to be shared & \multirow{3}{*}{$\begin{array}{l}\text { (an emergent theme from observation } \\
\text { data) }\end{array}$} \\
\hline & Sequential, Three-part lessons & \\
\hline \multirow[t]{5}{*}{ Focus group feedback. } & Solidify, repeat lessons & \\
\hline & Attention to, isolate, solidify concepts & Understand concepts \\
\hline & Foundation for a concept & \multirow{3}{*}{$\begin{array}{l}\text { (an emergent theme from Focus group } \\
\text { data) }\end{array}$} \\
\hline & Manipulating the process, the why & \\
\hline & Understanding and remembering & \\
\hline
\end{tabular}

To triangulate the transcripts and survey analyses, classroom observation notes and pictures, and the teacher documents were analyzed as shown in Table 4. Generation of nodes and themes: This analysis of the interview transcripts in NVivo generated nodes on both pre-existing nodes (such as of sections on the interview and of factors on the questionnaire) as well as emergent nodes from the data. Nodes were further clustered under broader subthemes that were at the time of writing merged into themes. Table 4 shows the teacher knowledge nodes, codes and themes identified in the data. At the focus group discussion with the research participants, when preliminary nodes were presented, participants made suggestions on what to include or exclude, and how to further organize the themes. The researchers then further interpreted the results using the study framework.

\section{RESULTS}

Teachers who participated in this study stated that they were trained to teach a three-year cycle (grade bands) at a time. They received training for each school subject at that grade level, and "the purpose, the procedure and in the concept" taught in the lessons. The training was hands-on and included opportunities to be "put in a classroom with one trained teacher."

The key findings on how Montessori teachers describe the knowledge they learned during their Montessori teacher training courses include: knowledge of use of Montessori concrete materials for respective three-year cycle, how to present Montessori lessons that utilized these materials, and the opportunities given to independently understand the mathematics concepts through, for example, the proper use of the materials. In this paper we report these three major findings on knowledge learned during the training as reported by the Montessori teachers who had been practicing for several years:

1. Learning the materials and their methods

2. The lessons and how to present them

3. Coming to understanding of concepts on one's own

When the preliminary findings were presented to the participants at the focus group discussion, they maintained that the core of these categories of a Montessori teacher's knowledge was the prepared learning environment as shown in Figure 1. The subsections report in detail these three key findings.

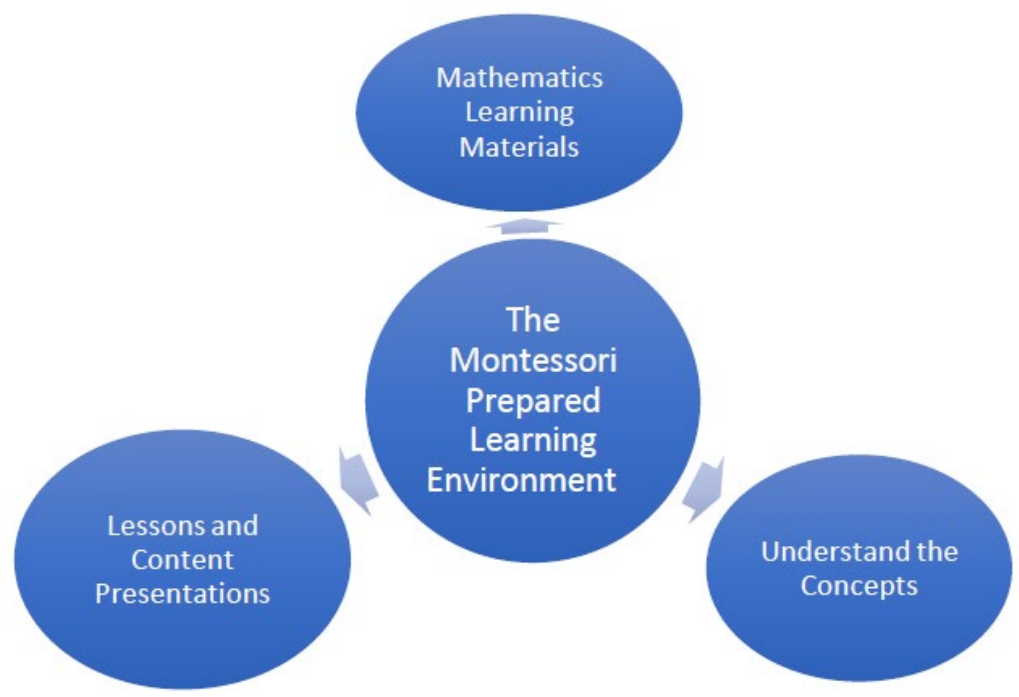

Figure 1. Montessori Mathematics Teacher Knowledge Components 


\section{Learning Materials and Methods}

Participants indicated that during teacher training they had learned that the Montessori curriculum was material-based, and the training was focused on the use and purpose of the materials. Therefore, teachers had opportunities to learn about the "concepts," "the materials," "how to use these materials properly," "engage the children with the material," and use the materials to "entice them [the students] into lessons." According to T07, it is difficult to "just walk into a Montessori classroom without training and be able to do it because you can't pull that material off ... you couldn't, you actually have to be physically trained on how to use the materials."

T06 described the training session and said, "the first two weeks of teacher training were on Maria Montessori ... her philosophy of learning, followed by training on materials and how to use the materials." When responding to further interview questions about the training in terms of how the knowledge obtained was reflected in the participants' approach to teaching as well as the importance of materials in the lesson, participants' responses indicated that teacher training involved learning the materials; that the curricular was material based. For instance, T07 stated that since their curricular was largely material-based, and also "based on real world questions, ... they teach you how to use every single piece of [Montessori] material that you would find anywhere in the world." T05 described the training process:

"You learn every piece of material and you learn how to teach the child with every piece of material in the classroom. ... your lower elementary training, grades 1, 2, 3, you go through all that material in the order that a child would learn it and the same as with the upper elementary. So, you start with the grade four materials and go all the way up to the grade six."

According to T06, the Montessori way of teaching math makes learners "feel very confident," therefore the materials also "help them [learners] develop their abstract thinking, say, if they have gotten to the point where they have abstracted the formula, then they can do it without the material." When asked about some of the specific kinds of materials they use, T11 stated, "we use flash cards, textbooks to expand their knowledge in, say, an area or perimeter of a square, so they show us how to do that accurately." Participants also indicated that they obtained training on attributions of Montessori physical learning materials. These attributes included color, form, size, texture and weight. T02 explained the importance of having knowledge of them, for instance "when we are using colored units; bars, and blocks [to teach addition and subtraction], our kids just know that green means units; and tens are blues." T02 continued to explain that, because "they [learners] have the opportunity to literally grab a ten bar, from the materials and drag it over, so now they actually see with their own eyes [when subtracting multi-digit numbers], ... also when you move one extra ten from the eight, it's not eight anymore it becomes seven hundred, not eight hundred; and it's not five any more; it's fifteen."

Material usage for teaching in Montessori classrooms was not only vital as indicated by participants, but also needed to be Montessori related, very purposeful and for specific lesson content. However, T05 indicated that, "slight differences and modification by institution may be acceptable," such as the bead material, depending on the society with which one received their teacher training.

Further, during the training, teachers had learned about how to, make an extension or modification to certain materials where needed to highlight connections to the real world of today without necessarily changing the focus of the specified lesson. T07 explained how they modified their lesson materials and connected the lesson to real world:

... if I was teaching the kids how to add, I would use the Montessori materials. But, because of the winter season, I might decide to create an extension where I use, like, snowmen and put four snowmen out; then five snowmen out; and put them together because they are learning how to add. Because they are seeing that adding is putting things together. So, we do allow extensions with our Montessori materials.

Although, teachers indicated that they may be able to modify some of their materials, some of the participants indicated that the focus on materials does not change and would only do so when students are working with "transitional" materials (from one grade to another or from concrete toward abstraction) or in "the transitional [to public school] grade band in grades 7-8" in their school in which students were prepared for public school because the city had no Montessori school after Grade 8 . Table 5 shows additional transcripts, excerpts, descriptive data and pictures on the theme of materials."

Teachers also mentioned that some of the materials they employ in their teaching method puts emphasis on real world contexts and applications such as "baking and cooking" [T01, T07, T11] in the classroom kitchens. T08 and T12 stated that, in the observed seminars students solved extended mathematics problems and projects such as designing and budgeting in the story of a teacher building a fire pit in their backyard. T08 added that "students in upper elementary and junior high also used textbooks, computers and other tools of their choice for specific mathematics tasks."

While most of the grades 6 to 8 teachers were speaking of their children using mostly transitional and abstract materials in their disciplines, Kindergarten teachers on the other hand, spoke about using materials and activities in the sensorial and practical life-discipline. Further excerpts and triangulation results are included in Table 5. The excerpts from the transcripts offer more examples on Montessori materials for different concepts. The excerpts from survey results show how teachers consistently ranked the practices of using learning materials in teaching and the elaborations they added when responding to the factor of teaching practices. The analysis of the teachers' documents shows the content of the materials and its categorization in the teachers' manual. 
Table 5. Transcripts, Excerpts, Descriptive Data and Pictures on Materials

\section{Interview transcript excerpts on materials and methods:}

T02: They go up to ten and they know how to exchange or take the unit back to the bank [a story context for the material with a place on the shelf] and then bring the ten, and they have the tens, they take it back to the bank and then they exchange for a hundred.

T011: Learn the square of nine is eighty-one and the cube of nine and there is ... that many beads in that nine cubes ... They can feel the weight of it, the difference .... It's very sensorial."

T07: A formula is more abstract but seeing it and how it works ... and being able to manipulate it and being able to turn that triangle into a rectangle.

T06: Through the training. They will always present the material to us and then they have us practice with it .... There are always various presentations within a piece of material too, you get shown the piece of material and you learn how to read the number off it. So she's got the checkerboard here I don't just plunk that in front of them I show them how to read the numbers off of it and try to explain it to them, I show them how to do a single digit multipliers, then we do double digit multipliers, triple or could do quadruple. But, usually after the double they say, "I get this." This material reappears in the upper level for decimals. So, it showed both whole numbers and decimal numbers... I would say things like ... and you would pick up on it like the terminology of units, tens, hundreds, thousands, millions. To learn the colors of the hierarchies the green, blue, the red, ... it's really the terminology.

Teacher Survey responses on materials and methods:

Consistence on the practice of using materials Prek to 6: On the survey, two questions on ranking 10 teaching practices, use of materials was ranked high (4.92 out of 5) as a most frequently used teaching practice, with only the 3 Junior high teacher participants ranking 4 other practices -textbooks, math problems, and homework higher.

One teacher, T03 explained on the short response question for this factor "manipulatives are important in "understanding key processes in math is best done through concrete experiences with materials, and "the experience the student has with the math materials greatly impacts their learning. Also, the sequence of materials and the age that the students are introduced to math concepts occur when they are developmentally ready for it."

Participants added teaching method on the list of practices by participants included: "allowing children to discover patterns and rules by handling the apparatus/concrete materials" and "progressing gradually from concrete to symbolic" T10; and Stories [T04]

\section{Teachers' documents exhibit on materials and methods:}

Organizations of the materials: The content of the Grades 1-3 teacher manual that was analyzed provided by one participant focused on how to organize and use the materials, both the tangible and the intangible (e.g., space for focus) materials. The ending sections of the manual included an annotated list of materials (physical manipulables, written and printed cards, frames, stamps, exercises, games, boards, charts, control charts, grid paper, apparatus, student writing booklets) organized by topics such as numbers, decimals, tables, and passage to abstraction Further, certain topics included presentations/materials that were categorized and labelled passage (transition) to abstraction. and other materials were labelled static (e.g., simple) or dynamic (e.g., multi digit involving exchange by going to the "bank" on the shelves).

Observation notes and pictures on materials and methods:

Use of a variety of sequenced materials: Figures $\mathbf{2} \mathbf{a}$ and $\mathbf{2} \mathbf{b}$ are pictures of a child in lower elementary working through a multiplication fact booklet to practise a lesson learned on multiplication facts using the following materials: a multiplication board, a corresponding set of number cards, beads, a red disc and a teacher-prepared multiplication booklet. In Figure 3 is corresponding notes recorded in the teachers' manual when the teacher learned the same procedure using similar materials. The child would then check the work using a control chart on multiplication, Control Charts 1, 2 (showing all the 100-basic multiplication fact). According to the teacher manual the child should be "about 6.5 years and should have addition and subtraction exploration steady."

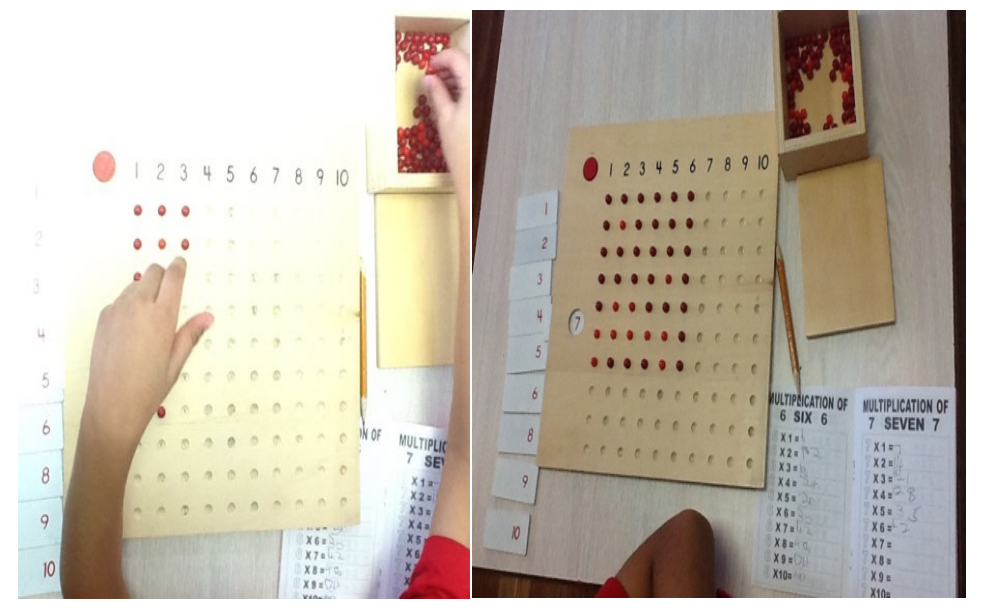

(a) (b)

Figure 2. A child's work on understanding multiplication facts. The lesson's name is multiplication facts - board in progress.

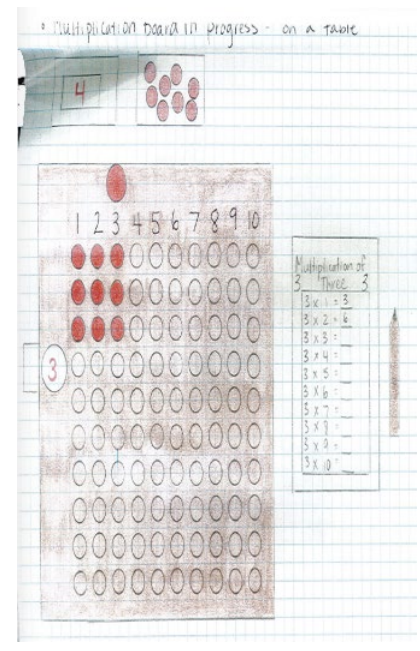

Figure 3. A teacher's notes in their manual for using the Multiplication Board along with Control Charts 1, 2

The findings also indicated that the teacher training process involved archiving knowledge of the use and purposes of materials through creating or assembling a teaching resource, also referred to as a manual or album: T11 added, "we have our teacher manuals ... that have, like, each piece of material and each concept in them." The content of the manual was in line with the response to the interviews and survey; as it showed a focus, during teacher training, on every single piece of material to use in teaching Montessori mathematics lessons. One participant concluded, a "major thing to know as a teacher is how to use these materials properly, ... Uhum that's why we have to do the training." 
Grades 7 and 8 teachers stated that they do not usually use physical materials in teaching, because learners have reached an abstract learning stage. T12 further explained, "we always try to get them engaged in using the material when they can, but if they have abstracted, say, if they have gotten to the point where they have abstracted the formula they hardly used them."

\section{Lesson and Content Presentation}

Lesson and content presentation were all about "learning the process ... it always starts with the material" [T06]. The training was "very hands on" [T08] and included opportunities to be "put in a classroom with one trained teacher" [T11]. During teacher training, participants said they had been offered learning opportunities on several aspects of mathematics lessons: They said they studied the sets of presentations for a topic; the use and methods of materials associated with the lesson; which classroom space to work in-table or learning mat or hall way-; the nature of associated teacher and students activity and interactions (e.g., when to talk, what to say, what to illustrate, and when to silently present the lesson to students, and what questions to ask the learners).

Teachers indicated that they learned how to use concrete materials to deliver lessons for specific grade bands and concepts. When asked how they learned knowledge of concepts for specific grade bands, T02 explained that they learned how "to use the concrete materials properly for each concept at the grade band" ... "the purpose, the procedure of the material and, in the end, the concept to be taught." T02 added, for example, that the concepts of number quantities and symbols, you learn "by touching it and feeling the weight of a thousand."

Teachers said that during teacher training, they had also read, studied and taken notes on each of the lessons as well as studied the learning competencies, such as independent explorations that are valuable to nurture in the learner. This process "allowed [teachers] to demonstrate the knowledge [they] have learned about the materials by reading [about] them from their notebooks and present a good lesson to the students" according to the philosophy [T06]. The lesson structure was outlined in detail for each concept in the teacher's manual; and this was better captured during observations than at interviews with the participants:

... it always starts with the materials; I wouldn't just give them a handout and not show them the material; ... uhum, they call it the 'three Period Lesson,' ... you start with the material; you present, and then you ask them [students] questions for follow up to make sure they understand. And then they repeat back. So that's typically how all the lessons work. If it's brand new [lesson] we'll start by showing them the lesson and then ask them [students] questions and have them repeat the answer or the formula to show that they understand it; and they do that right from CASA" [T07].

To add to how lessons were presented with specific materials, T07 indicated that, during the training, they were given opportunities, to work on a "pretend classroom and do a placement work" to mock-teach the lessons. Phrases used by the participants to describe the lessons included: 3-part lessons, lessons as gifts, 2 to 3-hour blocks, repeating lessons a few times, and giving a child a lesson follow-up before the child grasped the lesson. Teachers mentioned that the training on the lesson also included how to present the lesson to students. T11 described: "you can silently be giving the child a lesson and ... purposefully using the material and making eye contact with the child, you don't need to do so much of the talking." The lessons presentations were designed as relatively short presentations and immediately followed by a students' exercise such as working through a booklet. One participants teaching grades 1 to 3 mentioned that "I always say to my students, I see my lessons as gifts [as is the case with the materials], I am presenting them with a gift, something that I know that I appreciate and I find it very interesting and I want to share it with them." T06 added, "we do planning, ..., we have all the lessons written down, but we're hoping that interest [in the lessons] will come from them."

Participants also indicated that they do not always teach lessons. Some days were reserved for practice only: "Respect children's interest first, but there are lesson plans available" [In my classroom], "four math lessons were taught on Mondays to four different [small] groups in the same" classroom.... So, this is not a group that stays together; it's very dynamic how it's grouped ... the teaching groups based on the child's need." "Students [were then] set for about a week of working on their own, at their own pace, following the agenda book and might need an additional lesson in the week" [T05]. "We put them in groups for lessons and regroup them as needed, depending on interest [and need] levels in a new lesson" on a topic [T08].

To sum up how mathematics is presented in a Montessori classroom, T08 narrated, mathematics in Montessori was "built on the previous concept[s] ... You "learn every piece of material and you learn how to teach the child with every piece of material in the classroom."

Moreover, teachers mentioned that Montessori lessons are detailed, scripted, and sequenced. The teachers explained that the purpose that scripted and sequenced lessons served was to aid students' understanding and love for the subject. Therefore, to assist learners grasp the concept easily, T09 stated that "ready planned lessons on basics need to be taught first" and there is an established amount of lessons for a topic. Participants spoke of most mathematics lessons being originally scripted by Maria Montessori, with only few lessons being new in the mathematics curriculum. "We have our teacher manuals" "lots of reading and diagrams in it." "When you learned how to teach, you can go to your manual and pick up any concept you are teaching. It will basically tell you how to teach" [T07]. Therefore, the knowledge obtained from the training "assist us to recreate and update our materials as often as we feel needed" [T06]. "It also helped us to use the Montessori materials "to create stuff seasonally" like an extension of a lesson on order "to keep it fresh and current. ... so, we try to do refreshers remembering the purpose of the materials and to just go back to basics of Montessori and not all the stuff that we have added onto it [T09]."

Some of the teachers described why and how they modify lessons or create some material as a form of lesson extensions; as well as how important these modifications are to their lessons. T07 narrated:

... I really sat down, and we made the materials ... It's very personal, right, and we made it for them, so it's almost like a gift, okay, we feel you need it, we feel you're gonna benefit from it, so here we go; we are going to make this for you. So, 
Table 6. Transcripts, Excerpts, Data and Pictures on the Theme on Lesson Presentation

\section{Interview transcript excerpts on Montessori lessons and their presentations:}

T05: When they are not in math lessons ... they could be doing history, [or] ... they are independently just doing their work.

T06: The Montessori lesson ..they call it the "Three Period Lesson." you start with the material, you present, and then you ask them those questions for follow up, ... like I did to make sure they understand. And then they repeat back. So that's typically how all the lessons work" T07: It's a little bit of both having the material, I mean having the album which gives me the lesson ... would just review the lesson in the album, ... get out the materials and ... probably should do it once before ... to either my co-teacher or ... to myself to make sure that I do it properly before I go and do the lesson with the kids, also it gives me an opportunity see what I forgot to do.

T08: I don't worry about teaching any lessons in math you know, I love it and I feel very confident in all the lessons I can give to all the children and I feel like I know what I'm doing because of that then they learn really well as well.

T012: In the lesson, you saw that we were able with the material to change ... the triangle into the rectangle, to show that it does have the same area, yet you can't always do ... so then we go forward and show how we're actually finding half the height or half the length.

\section{Teacher survey responses on Montessori lessons and their presentations:}

Scores on all factors on the survey were on the reform side except for specific questions on lessons: Beliefs about mathematics (Factor 1 ; mean 3.89 out of 5 on the long from; 4.0 out of 6 on short form); Beliefs about learning mathematics (Factor 2 ; mean of 4.09 long form; 4.3 out of 6 on short form) and beliefs about teaching mathematics (Factor 3; 3.94; 4.1).

Analysis of disaggregated responses on six survey questions which showed much lower (between 2 to 3.0 ) than the means on each factor:

1. Mathematics is computation, definitions and procedures (Mean 2.71).

14. Being able to memorize facts is critical in mathematics learning (2.43)

19. Basic mathematics skills need to be taught first before students engage in open-ended problem-solving activities (2.86).

38. It is the teacher's responsibility to provide children with clear and concise solutions methods for mathematical problems (2.43).

39. There is an established amount of mathematical content that should be covered at each grade level (2.71).

40. It is important that mathematics content be presented to children in the correct sequence (2.00)

Further, Teacher T03, noted on the questionnaire that "Montessori's approach to math is very methodical, sequenced, so the way math is taught does not vary, but gaining ideas for further explanation is great."

The items with much lower means and this elaboration revealed specific participants' beliefs which were of platonic mathematics content, of learning as internalizing knowledge and of teaching as telling the proper use of materials for learning procedures and concepts, and certain mathematics content, skills and solutions needed to be taught first taught by the teacher:

Teacher document exhibits on Montessori lessons and their presentations:

A section on "three period lesson: (give the name, show me, what is this?") was part of the teacher's manual. An example of a write-up of the lessons and their illustrations, organized under topic, and their details, formed the body of the manual and is shown in Figure 4. In addition to the list of materials to be used the lesson presentation is described including details of the actions, what to say and question to ask when presenting the lesson. Figures $\mathbf{5}$ to $\mathbf{6}$ show what the teacher writes on a board for the students to see and does during the lesson.

Further, the checklist in the teachers' manuals showed mathematics topics for the grade level organized by subtopic/exercise/lesson title (e.g., kind of operation activity and illustrations of how materials are explained). More than one presentation and exercises were specified per topic. Also, the purpose and age, and pre-requisite were specified for each lesson. For some lessons, a control of error section was added. Other lesson details included: notes such as if the children can work together or separately.

Observation notes and pictures on Montessori lessons and their presentations

In the lessons observed, pictures were taken of lessons such as the grade 1 to 3 decimal additions taught to a small group of students seating on the floor. In Figure 5, students are sitting in a semicircle around the while board and materials used by the teacher during a "adding of decimal" lesson. Figure 6 shows a multi-digit addition lesson demonstrated by the teacher on a learning mat. Figure 7a and $7 \mathbf{b}$ are for a lesson on formula of a triangle in relation to that of a rectangle taught to grades 4 to 6 students. All three lessons were taught to a small group of learners.

we made it, we laminated it, it's on the shelf; sitting there nicely... We are constantly updating them. At least once a year, ... we generally make a lot of new materials, we put old ones away, we make new ones, right, actually the week after the kids are done school ... what we call work week."

T05 also added, "if I don't have all the materials, I can make some of them or make what I need to do or sometimes we can come up with lessons that will further the idea of a concept. Table 6 shows additional transcripts, excerpts, descriptive data and pictures on the theme of lesson and content presentations.

In terms of classroom space that learners work in, and the nature of associated teacher and students' activity, teachers said multiple lessons were taught in a classroom on a day, at times, concurrently. In addition, multiple learning materials used were in certain lessons. Advantages of teaching multiple lessons in the same class mentioned by participants included: the possibility of having the older children help the younger children, and the older kids realizing prior lessons that they took before when they see these taught to younger children in class. T07 added, "we have multiple materials for teaching a lesson, ... this allows the children to use each material, to take their time to use each material and to really love all the lessons that we're giving to them ... and to try not to be afraid of others."

Further excerpts and triangulation results are included in Table 6. The excerpts from the transcripts offer more elaboration on Montessori lessons and their presentations. The excerpts from survey results show teachers' beliefs on three factors on the survey and an analysis of disaggregated responses on six survey questions which showed much lower means and the elaborations participants added when responding to the factors. The analysis of the teachers' documents shows the details in the teachers' manual on the materials to be used in the lesson presentation of the specified actions of the teacher when presenting the lesson. 


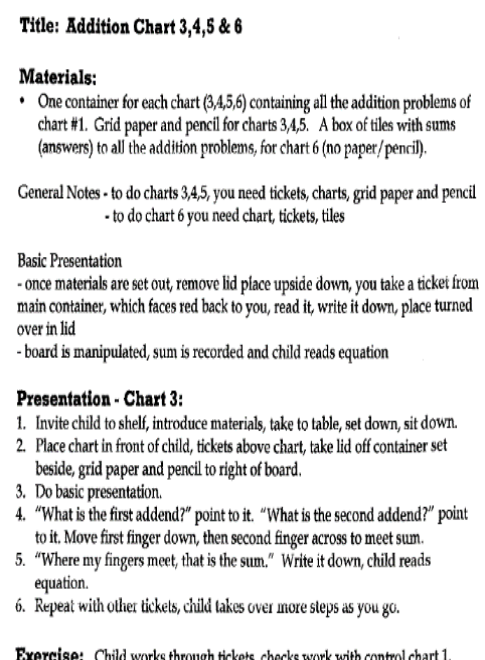

Exercise: Child works through tickets, cherks work with control chart

Figure 4. Example of a lesson presentation on an addition facts table lesson presentation

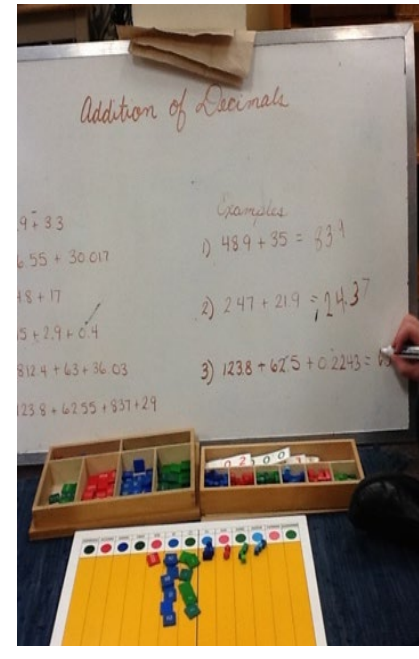

Figure 5. A decimal addition

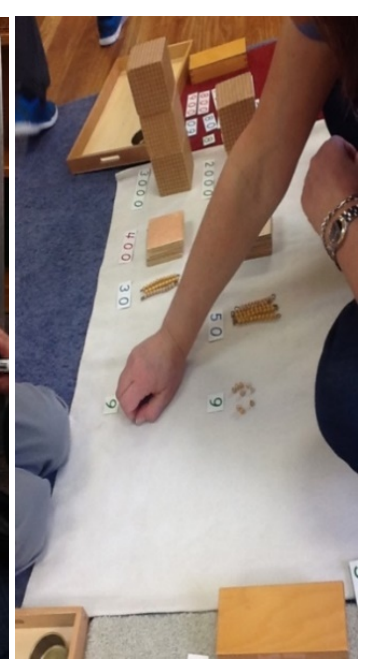

Figure 6. A multi digit

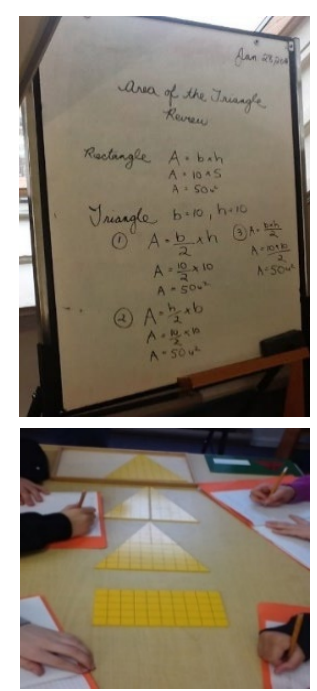

Figure 7. A lesson on area addition lesson presentation of a triangle formula

Teachers spoke about learning to regulate the noise level during their multiple lessons in same room, as T06 explained, "sometimes that's the challenge in a Montessori classroom, because if you're doing small lessons and the other students in the class who are doing other things ... it can get quite noisy." As a result, teachers learn to keep the noise level and "buzz of activity" in a Montessori classroom, as "obviously not too big, but you always want it not to be a noisy environment." [T07].

\section{Independently Coming to Understanding Concepts}

One theme that was not identified as a distinct theme until the focus group was the teacher knowledge of coming to independently understand a concept first by the teacher and then learning to create an environment for students to independently understand this concept. A teacher stated that teachers learned "how to have that concrete experience to be able to understand mathematics" [T06]. T03 added, "it made me enjoy math again after doing the training, because of working with the materials and seeing why things are done the way they are ...." Teachers gave examples of concepts they now understand better as shown in Table 7. T08 excitedly stated, "my math has been improved through working with these materials and teaching of these concepts, thanks to the knowledge we received from the training" such as on repeated adding, multiplication, exchanging, hierarchies of numbers, multiplying by the hierarchies. T02 also said: "I put a zero there because I am multiplying by a ten, when you multiply a ten it can't go in the unit column, it has to move over. Holy cow! This makes much more sense."

Teachers independently coming to know a concept also applied to how they said they were trained to teach in classroom:

"I will do anything to try to present material in a way or give them [learners] access to concepts in a way that will allow them to learn that. There is nothing better than watching somebody to go from not understanding anything to understanding it" [T08].

"So, for a teacher to understand that concept, I think it's great." For example, "the flat chain folds up into a square; you can take that hanging chain and you can actually see the squares there; and it would fold up to make the cube" [T07]

Teachers needed knowledge of how to wait for students to demonstrate learning on a prerequisite concept before they moved on to teach the next concept: "And you watch that child and you wait until [he/she] has solidified a concept before you move onto the next concept" [T06]. Two participants mentioned that this way of learning, which is mainly material-based, was: "very different ... I wish that I had learned this way, it would have made much more sense to me," [T09] "if I had that material when I was doing math." The benefits of these aspects of teacher knowledge included: "they [students] feel rewarded with mastering something and feeling very accomplished." T08 spoke about a co-teacher, who was both a Montessori-trained teacher and a Montessori alumnus: "her ideas are amazing."

Teachers mentioned that certain aspects of teacher knowledge for teaching the Montessori curricular were very specifically helpful for mathematics concepts: physical materials-"they have to have that concrete experience to be able to understand math"; presenting lessons to small groups-"learning in a small [group] environment"; observing for understanding-no moving on to the next lesson "until you know that little Jimmy gets it."

Teachers noted that although they were trained on how to guide children develop some kind of understanding about the materials as they interact and engage in activities on their own, on the other hand they have difficulty guiding certain children because "some children coming from the public system have a hard time to pick up the patterns of the materials" [T09].

Further excerpts and triangulation results are included in Table 7. The excerpts from the transcripts offer elaboration on understanding of concepts in Montessori teaching. Excerpts from survey results on the teachers' beliefs on learning and understanding mathematics, the comfort/anxiety scale, on focusing on students' enjoyment in learning mathematics are presented. Additionally, the analysis of focus group feedback that showed the importance of understanding concepts is added. 
Table 7. Transcripts, Excerpts, Descriptive Data and Pictures on Understanding Mathematics

\section{Interview Excerpts on Independently understanding the mathematics concepts}

T01: In our philosophy the children work for themselves.

T02: "understanding the idea, but if it's not right yet that's ok, ... we'll keep working on that."

T06 "it's just thorough understanding and being able to recall it, like definitions of things and ... when they need or when there's a need to use it.

T07: I remember back when I went to public school learning ... not really understanding how, what the process was to get that formula you know.

T08: the process and understanding the process, comes before the right or wrong. The right or wrong just happens with the precision that they develop."

T04: the bead frames for some children, ... they struggle ... just understanding that whole process they just can't get [it]. So sometimes you have to change the strategy of how we are trying to teach the child that concept

T08: understanding the concept of area and ... understanding how to find the area of a rectangle and triangle. And understanding how the area of a triangle is related to the area of a rectangle.

T09: "I keep on thinking that you cannot understand math if you don't have the experience as I said before I keep going back to the weighing of numbers." ... "they have to have that concrete experience to be able to understand math."

\section{Survey Data on understanding concept:}

One participant added on their questionnaire that "I understood math concepts much better after taking Montessori Teacher Training" and Understanding key processes in math is best done through concrete experiences with material" [T07]

Further, on the questionnaire teachers' beliefs about learning mathematics, Factor 2, were more on learning through construction than internalizing knowledge (Mean 4.09 out of 5; 4.3 out of 6 on the short form) than beliefs about mathematics (Factor 1; mean 3.89 out of 5 on the long from; 4.0 out of 6 on short form); and beliefs about teaching mathematics (Factor $3 ; 3.94 ; 4.1$ ).

On the comfort/anxiety scale, all but two teachers reported mostly moderate to high comfort levels. Two teachers reported moderate to extreme anxiety at learning mathematics. When asked how comfortable teachers were at teaching mathematics none of the four teachers who completed the short form reported being uncomfortable. Two of the teachers specified that they were very comfortable for the level "they were trained" for or "they teach."

On Factor 6, included questions on understanding and enjoying mathematics: all 12 participants consistently ranked the importance of mathematics enjoyment highly (Mean 4.36 out of 5). Specifically, participants' responses to the question of understanding before memorizing were consistently high (mean 4.36 out of 5; T02 left this question blank), and "using activities that show that all children can do math when they think and work hard is key in learning mathematics" (mean 4.25). All 12 participants consistently ranked the importance engaging students in understanding before memorizing at Mean 4.5 out of 5 .

\section{Focus group feedback on the prepared mathematics learning environment:}

At the focus group, teachers noted the teacher knowledge of both learners and teachers independently coming to understand a concept was a key aspect of teacher knowledge.

T06: Mathematics is "all about the concrete experience, they have to have that concrete experience to be able to understand math, so I keep on thinking that you cannot understand math if you don't have the experience as I said before.

T10: When its math related [when organizing materials on the shelves] we try to go from less challenging to more challenging, that's how we organize the environment. You'd never teach how to divide before you subtract or something..... Math is very logical so you can't do it very willy nilly.

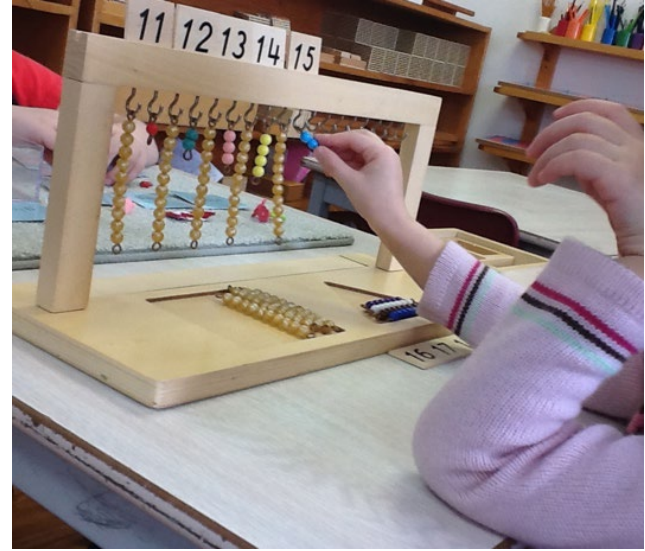

Figure 8. A student practising for understanding two-digit numbers on a frame-glass bead materials

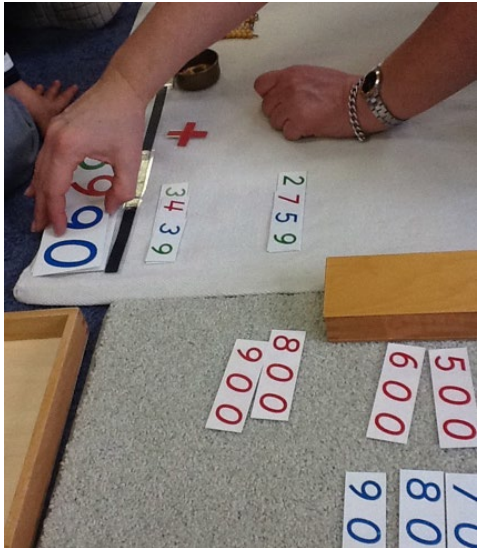

Figure 9. A teacher presenting addition of multidigit numbers, layering ones overc tens over hundreds

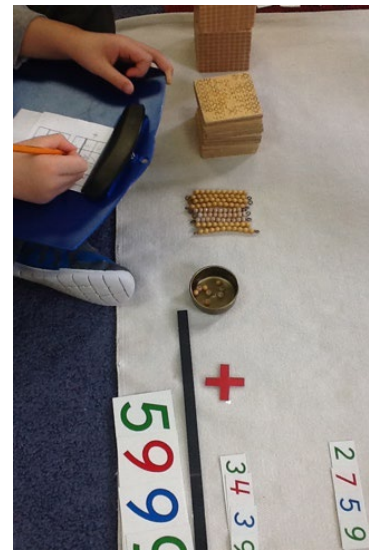

Figure 10. As student writing down on a booklet with a table to further understand the addition

\section{DISCUSSION OF FINDINGS}

\section{Mathematics Teacher Knowledge and Teaching Ecosystem}

Our study focused on teacher knowledge for teaching in an education system as characterized by the Montessori curriculum, learning philosophies, classroom and assessment practices (Bagby \& Sulak, 2010; Erwin et al., 2010; Lillard, 2011). Akin to Kayili and Ari (2011), Kuennen and Beam (2020), and Laski et al. (2016), our study looked specifically at mathematics teaching particularly teacher knowledge needed, used and further honed by teachers to teach mathematics. Findings of this study are in 
line with literature on the Montessori education system: The finding on teacher knowledge of Montessori learning materials and how to properly use them is in line with the Montessori principles on provision of a detailed curriculum and support resources for teaching this curriculum (Bărbieru, 2016; Kayili \& Ari, 2011; Lillard, 2005; Ross, 2012), and is in line with the extensive use of materials (Kuennen \& Beam 2020; Lillard \& Else-Quest, 2006; Marshall, 2017; Ross, 2012). Even when the materials were diverse and the lessons much detailed, the teachers appeared to be trained in the same mathematics with which they were expected to teach students in classrooms, and many agreed that they learned to comfortably teach mathematics differently than they were taught when they went to school.

The finding on teacher knowledge of the lessons and how to present them are in line with the Montessori classroom practices that appear to involve routines and rituals (Cossentino, 2005), and the form of teaching and learning that remain largely unchanged from the time that it was conceptualized (Lillard, 2007). The finding on teacher knowledge on the purposes of the materials, lessons, is in line with Lillard's (2007) assertion that this pedagogy is intended to make students develop productive capabilities such as understanding of mathematical concepts, confidence at learning mathematics, as well as the virtue of independent learning skills (Bagby \& Sulak, 2010; Bărbieru, 2016; Lillard \& Else-Quest, 2006). The findings from this study add to a body of knowledge on Montessori mathematics education specifically, on teacher knowledge needed for teaching mathematics.

\section{Mathematics Teacher Knowledge and Categories of Teacher Knowledge}

We applied the analytical framework developed on teacher knowledge to interpret our findings on teacher knowledge that Montessori teachers need, use and hone. Table 8 shows the mapping of the themes in the four categories. For example, the theme of teacher learning and knowledge on the use and methods of learning materials fit into the framework category of teaching aspects. But there is more including how it also fits in the learning aspect.

Table 8. Mapping of the Four Montessori Teacher Knowledge Themes

\begin{tabular}{ll}
\hline Montessori Teachers' Knowledge Themes & Teachers' Knowledge Framework category \\
\hline Learning materials & Teaching aspects $\rightarrow$ \\
\hline Lesson and content presentation & Learning aspects $\rightarrow$ Curriculum aspects \\
& A teaching aspect $\rightarrow$ \\
\hline Independently coming to the understand concepts & A professional competencies aspect \\
\hline$\rightarrow$ Stands for in between the two aspects & Curriculum aspects $\rightarrow$ Learning aspects
\end{tabular}

$\rightarrow$ Stands for in between the two aspects

All three themes fit in more than one category. For example, teacher knowledge on the lesson and its presentations fits in both the teacher aspect and the professional competencies aspect, and the understanding of mathematical concepts which, during the training for the teacher was intended to show how to help the learner with independently coming to understand mathematics concepts. This finding is in line with the assumptions that categories are not always mutually exclusive. But there might be more: The framework in its current form, although helpful for categorizing the Montessori teacher knowledge, might need further dimensions to cover themes that take on a different meaning in the Montessori system than in the public education system.

Planning for teaching and learning, enacting the lesson plans, observing lessons, analyzing and reflecting on the implemented lesson is a teaching aspect of teacher knowledge (Guerriero, 2014; Kuennen \& Beam, 2020). Teachers learning knowledge of specific lessons and how to teach the lesson within a philosophical framework is, on the other hand, a professional competence. Thus, the theme of lesson and content presentation also fits in both teaching and professional aspects. Further, the Montessori lesson is an authored performance with a script and specified presentations and interactions (Beatty, 2011). It is learned by the teacher and rehearsed during teacher training and recorded in a teacher's manual for use in practice. Then, while in practice, the lesson is further practiced, mastered and refined (or in rare cases extended or revised) in collaboration with at least one other teacher of the same class. Thus, teacher content knowledge is tightly connected to lessons taught by teachers (Clarke et al. 2007; Kuennen \& Beam, 2020) in the Montessori system.

Further, in the Montessori system, teacher knowledge on the methods, sequence and proper use of materials is a teaching aspect. This teaching aspect begins with a teacher having in-depth learning about the piece of material. Thus, it is a teacher learning of content aspect of teacher knowledge. When the materials are well understood by teachers, the materials then become key to the understanding of content first by the teacher; and then by the student. The materials, technologies and apparatus to be used to teach mathematics are also a much closer part of the school curricular content knowledge to be taught to the students.

Teacher knowledge on curriculum and content concepts appeared to also apply to understanding materials, including control charts drawn and transitional materials, activities and procedures, the knowledge of the sequences of lessons, and the process of coming to understand the concepts. We continue to ponder how the findings of this research elaborate on the categories of teacher knowledge identified in the framework.

Table 9. Sub-categories of Montessori Mathematics Teacher Knowledge

\begin{tabular}{ll}
\hline Broader theme of repetition & Learning of broader themes: \\
Contexts aspects & - within mathematics e.g., repetition \\
& - cutting across materials e.g., color coding \\
& - repetition of lessons for students to benefit \\
& - regularity in organizing the environment \\
\hline
\end{tabular}

The subthemes on use of scripted lessons, some of which are expected to be repeated until students understand the concepts, appeared to address equity along the spectrum of fast and slow learners as well as context aspects. Further, this study's findings show that beliefs of the mathematics teachers are intertwined with the opportunities they are offered to learn mathematics teaching knowledge during teacher training. 
According to Kutaka et al. (2017), and Sewornoo (2016), the concept of beliefs plays a huge role in teaching and learning as well as classroom practices. Teacher knowledge in the Montessori system is based on a specific learning theory, the learning aspects of Montessori philosophy. Teachers believe in learning mathematics through Montessori activities, lessons, materials and coming to understand the mathematics concepts, which are taken to be mostly static and have not much changed. The teacher learned during teacher training how to entice the learners to the lesson and content in line with "customization of content and instruction" (Schneider, 2012), and child-centered and interest (Cossentino 2005; Faryadi, 2007; Kayili \& Ari, 2011).

Flexibility was also seen in having a sequence of materials, including transitional materials, to teach the same concepts, and in teachers engaging in making or revising certain lessons and their materials or presentations. More flexibility was seen in the other learning materials including selecting real world contexts, problems and stories to use in teaching, teaching in a team and fluidity in student grouping when teaching a lesson. Still, this flexibility took place within the limits of scripted lesson activities and presentations; classroom routines and rituals of the prepared learning environment; specific lesson presentation, proper sequencing of lessons, methods and use of the original materials and methods as conceptualized by Maria Montessori or published by selected Montessori organizations. Thus, teacher knowledge needed, practiced and refined is within inflexible limits. This dialectic between flexibility and rigidity is worth further investigation, specifically from the lived experiences of teachers and students. How is this complexity experienced?

The study raises questions on the mathematics teacher knowledge itself. How much of this knowledge could be taken as static and how much as changing? How might teachers in the Montessori setting and elsewhere navigate the delicate spectrum such as being flexible within limits, be creative within prescribed lessons, preparation of the environment and use of materials?

\section{CONCLUSION AND SIGNIFICANCE OF THE STUDY}

From our results, Montessori teacher knowledge is akin to teacher knowledge for teaching in a material and tool-based curriculum, teaching and assessment reform. At the transition grades, when teachers use more stories, real world contexts, projects and math problems, Montessori teacher knowledge aligns more with problem-solving based reform. It is evident that at the center of mathematics teacher knowledge is teaching for understanding and for enhancing affective outcomes of the learner.

Educational systems that have implemented mathematics educational reform consistently in curriculum, pedagogy and assessment, over the years, are rare. From the literature, further theorizing on sub-categories of teacher knowledge is needed to inform implementing reform in instruction and in teacher education. The findings from this study, therefore, strongly hold promise to inform mathematics teacher learning that supports productive mathematics instructional reform. The findings are particularly significant for designing teacher education course content and learning experiences that support the learning of reform instructional practices among preservice teachers.

\footnotetext{
Author contributions: Both authors have sufficiently contributed to the study, and agreed with the results and conclusions.

Funding: Funding for this study was provided by the Research Office, Western Education, Western University.

Declaration of interest: No conflict of interest is declared by authors.

Acknowledgements: We acknowledge the contributions of the research participants and their school administrator. We would also like to acknowledge the graduate research assistants who contributed to this work, including Hiba Barek, Campigotto Rachelle, Marja Bertrand, and Hatice Beyza Sezer.
}

\section{REFERENCES}

Ashrf, J. (2019). Experiences and impact: The voices of teachers on math education reform in Ontario, Canada. Glocal Education in Practice: Teaching, Researching, and Citizenship BCES Conference Books, 2019, Volume 17. Sofia: Bulgarian Comparative Education Society. Retrieved July 14, 2020, from https://files.eric.ed.gov/fulltext/ED596920.pdf

Bagby, J., \& Sulak, T. (2009). Strategies for promoting problem solving and transfer: A qualitative study. Montessori Life, 21(4), 3842.

Bagby, J., \& Sulak, T. (2010). Connecting educational theory and Montessori practice. Montessori Life, 22(1), 8-9.

Ball, D. L. (2002). Knowing mathematics for teaching: Relations between research and practice. Mathematics and Education Reform Newsletter, 14(3), 1-5.

Ball, D. L., Lubienski, S., \& Mewborn, D. (2001). Research on teaching mathematics: The unsolved problem of teachers' mathematical knowledge. In V. Richardson (Ed.), Handbook of research on teaching (pp. 433-456). Macmillan.

Bărbieru, I. T. C. (2016). The role of the educator in a Montessori classroom. Romanian Journal for Multidimensional Education/Revista Romaneasca Pentru Educatie Multidimensionala, 8(1), 107-123. https://doi.org/10.18662/rrem/2016.0801.07

Battey, D., \& Franke, M. (2008). Transforming identities: Understanding teachers across professional development and classrooms. Teacher Education Quarterly, 35(3), 127-149.

Beatty, B. (2011). The dilemma of scripted instruction: Comparing teacher autonomy, fidelity, and resistance in the Froebelian Kindergarten, Montessori, direct instruction, and success for all. Teachers College Record, 113(3), 395-430.

Belova, N., Eilks, I., \& Feierabend, T. (2015). The evaluation of role-playing in the context of teaching climate change. International Journal of Science and Mathematics Education, 13, 165-190. https://doi.org/10.1007/s10763-013-9477-x 
Blömeke, S. (2014). Framing the enterprise: Benefits and challenges of international studies on teacher knowledge and teacher beliefs--modeling missing links. In S. Blömeke, F. J. Hsieh, G. Kaiser \&W. H. Schmidt (Eds.), International perspectives on teacher knowledge, beliefs and opportunities to learn, Advances in mathematics education (pp. 1-10). Springer. https://doi.org/10.1007/978-94-007-6437-8_1

Browne, E. (2005). Structural and pedagogic change in further and higher education: A case study approach. Journal of Further and Higher Education, 29(1), 49-60. https://doi.org/10.1080/03098770500037754

Burton, L. D. (2003). The formal, the planned, and the learned curriculum in an elementary education course for mathematics: Three perspectives on course content [Paper presentation]. $2^{\text {nd }}$ Annual General Meeting of the American association for the Advancement of Curriculum Studies, Chicago, Illinois.

Cañadas, M. C., Gómez, P., \& Rico, L. (2013). Structure of primary mathematics teacher education programs in Spain. International Journal of Science and Mathematics Education, 11, 879-894. https://doi.org/10.1007/s10763-013-9422-z

Carpenter, T. P., Fennema, E., \& Franke, M. L. (1996). Cognitively guided instruction: A knowledge base for reform in primary mathematics instruction. The Elementary School Journal, 97(1), 3-20. https://doi.org/10.1086/461846

Chipangura, A., \& Aldridge, J. (2017). Impact of multimedia on students' perceptions of the learning environment in mathematics classrooms. Learning Environments Research, 20(1), 121-138. https://doi.org/10.1007/s10984-016-9224-7

Christle, C. A. (2010). Montessori Schools. In T. Hunt, J. Carper, T. Lasley, \& C. Raish (Eds.), Encyclopedia of educational reform and dissent. Sage Publications.

Clarke, D., Goos, M., \& Morony, W. (2007). Problem solving and working mathematically: an Australian perspective. ZDM Mathematics Education, 39(5), 475-490. https://doi.org/10.1007/s11858-007-0045-0

Cohen, L., Manion, L., \& Morrison, K. (2007). Research methods in education (6 ${ }^{\text {th }}$ ed.). Routledge Falmer. https://doi.org/10.4324/9780203029053

Cossentino, J. (2005). Ritualizing expertise: A non-Montessorian view of the Montessori method. American Journal of Education, 111(2), 211-244. https://doi.org/10.1086/426838

Cossentino, J. M. (2006). Big work: Goodness, vocation, and engagement in the Montessori method. Curriculum Inquiry, 36(1), 6392. https://doi.org/10.1111/j.1467-873X.2006.00346.x

Cossentino, J. M. (2009). Culture, craft, \& coherence: The unexpected vitality of Montessori teacher training. Journal of Teacher Education, 60(5), 520-527. https://doi.org/10.1177/0022487109344593

Creswell, J. W. (1998). Qualitative inquiry and research design: Choosing among five traditions. Sage Publication.

Davenport, L. R. (2000). Elementary mathematics curricula as a tool for mathematics education reform: Challenges of implementation and implications for professional development. Newton, MA: Center for the Development of Teaching (CDT) Paper Series, Education Development Center.

Debs, M. C. (2019). Diverse parents, desirable schools: public Montessori in an era of school choice. Harvard Education Press.

Diamond. \& Lee. K. (2011). Interventions shown to aid executive function development in children 4 to 12 years old. Science, 333(4045), 959-64. https://doi.org/10.1126/science.1204529

Drake, C. (2006). Turning points: Using teachers' mathematics life stories to understand the implementation of mathematics education reform. Journal of Mathematics Teacher Education, 9(6), 579-608. https://doi.org/10.1007/s10857-006-9021-9

Eacott, S., \& Holmes, K. (2010). Leading reform in mathematics education: Solving a complex equation. Mathematics Teacher Education and Development, 12(2), 84-97.

Elkin, M., Sullivan, A., \& Bers, M. U. (2014). Implementing a robotics curriculum in an early childhood Montessori classroom. Journal of Information Technology Education: Innovations in Practice, 13, 153-169. https://doi.org/10.28945/2094

Elkind, D. (2008). The power of play: Learning What Comes Naturally. American Journal of Play, 1(1), 1-6.

Ellis, M., \& Berry III, R. Q. (2005). The paradigm shift in mathematics education: Explanations and implications of reforming conceptions of teaching and learning. The Mathematics Educator, 15(1), 7-17.

Ervin, B., Wash, P. D., \& Mecca, M. E. (2010). A 3-year study of self-regulation in Montessori and non-Montessori classrooms. Montessori Life, 22(2), 22-31.

Faryadi, Q. (2007). The Montessori paradigm of learning: So, what? Retrieved December 17, 2019, from https://files.eric.ed.gov/fulltext/ED496081.pdf

Faryadi, Q. (2017). The application of Montessori method in learning mathematics: An experimental research. Open Access Library Journal, 4, 1-14. https://doi.org/10.4236/oalib.1104140

Franczak, I. (2016). Comparative analysis of behavioral engagement and transferable skills in conventional and Montessori schools. Proceedings of The National Conference on Undergraduate Research (NCUR) 2016 University of North Carolina, Asheville. April 7-9, 2016.

Fritzlar, T. (2006). Sensitivity to complexity- an important prerequisite of problem-solving mathematics teaching. ZDM Mathematics Education, 38(6), 436-487. https://doi.org/10.1007/BF02652780

Guerriero, S. (2014). Teachers' pedagogical knowledge and the teaching profession. American Education Research Journal, 47(1), 133-180. 
Herrera, T. A., \& Owens, D. T. (2001). The "new new math?": Two reform movements in mathematics education. Theory into Practice, 40(2), 84-92. https://doi.org/10.1207/s15430421tip4002_2

Ingvarson, L., Schwille, J., Tattoo, T.M., Rowley, G., Peck, R., \& Senk, S. L. (2013). An analysis of teacher education context, structure, and quality-assurance arrangements in TEDS-M countries: Findings from the IEA teacher education and development study in mathematics. Amsterdam, Netherlands: International Association for the Evaluation of Educational Achievement. Retrieved September 15, 2019, from https://heefa.net/files/TEDS-M_Findings.pdf

Jamilah, R. J. (2018). Predominantly Black institutions and public Montessori schools: Reclaiming the "genius" in African American children. Multicultural Learning and Teaching, 13(1), 1-7. https://doi.org/10.1515/mlt-2017-0007

Kayili, G., \& Ari, R. (2011). Examination of the effects of the Montessori method on preschool children's readiness to primary education. Educational Sciences: Theory and Practice, 11(4), 2104-2109.

Kuennen, E. W., \& Beam, J. E. (2020). Teaching the mathematics that teachers need to know: Classroom ideas for supporting prospective elementary teachers' development of mathematical knowledge for teaching. In A. Appova, R. M. Welder, \& Z. Feldman, (Eds.), Supporting Mathematics Teacher Educators' Knowledge and Practices for Teaching Content to Prospective (Grades K-8) Teachers. Special Issue: The Mathematics Enthusiast, ISSN 1551-3440, vol. 17, nos. 2 \& 3, pp. 771-805.

Kutaka, T. S., Smith, W. M., Albano, A. D., Edwards, C. P., Ren, L., Beattie, H. L., Lewis, W. J., Heaton, R. M., \& Stroup, W. W. (2017). Connecting teacher professional development and student mathematics achievement: Mediating belonging with multimodal explorations in language, identity, and culture. Journal of Teacher Education, 68(2), 140-154. https://doi.org/10.1177/0022487116687551

Lang, M., \& Namukasa, I. K. (2011). Problem solving as a pedagogical practice: Useful conceptions of professional learning. Literacy Information and Computer Education Journal (LICEJ), 1(4), 1-12.

Laski, E. V., Vasilyeva, M., \& Schiffman, J. (2016). Longitudinal comparison of place-value and arithmetic knowledge in Montessori and non-Montessori students. Journal of Montessori Research, 2(1), 1-15. https://doi.org/10.17161/jomr.v2i1.5677

$\mathrm{Li}, \mathrm{Q}$, \& Ni, Y. J. (2011). Impact of curriculum reform: Evidence of change in classroom practice in the mainland China. International Journal of Educational Research, 50, 71-86. https://doi.org/10.1016/j.ijer.2011.06.003

Lillard, A. S. (2005). Montessori: the science behind the genius. Oxford University.

Lillard, A. S. (2006). Dissociations, developmental psychology, and pedagogical design. Child Development, 77(6), $1563-1567$. https://doi.org/10.1111/j.1467-8624.2006.00959.x

Lillard, A. S. (2007). Montessori: The science behind the genius (2nd ed.). Oxford University Press.

Lillard, A. S. (2011). What belongs in a Montessori primary classroom? Results from a survey of AMI and AMS teacher trainers. Montessori Life, 23(3), 18-32.

Lillard, A. S. (2012). Preschool children's development in classic Montessori, supplemented Montessori, and conventional programs. Journal of School Psychology, 50(3), 379-401. https://doi.org/10.1016/j.jsp.2012.01.001

Lillard, A. S. (2013). Playful learning and Montessori education. American Journal of Play, 5(2), 157-186.

Lillard, A. S. (2018). Rethinking education: Montessori's approach. Current Directions in Psychological Science, 27, 395-400. https://doi.org/10.1177/0963721418769878

Lillard, A. S. (2019). Educational Psychology Review, 31, 939-965. https://doi.org/10.1007/s10648-019-09483-3

Lillard, A. S., \& Heise, M. J. (2016). Removing Supplementary materials from Montessori classrooms changed child outcomes. Journal of Montessori Research, 2(1), 16-26. https://doi.org/10.17161/jomr.v2i1.5678

Lillard, A., \& Else-Quest, N. (2006). Evaluating Montessori education. Science, 313(5795), 1893-1894. Retrieved July 19, 2020, from https://doi.org/10.1126/science.1132362

Litster, K., Moyer-Packenham, P. S., \& Reeder, R. (2019). Base-10 Blocks: a study of iPad virtual manipulative affordances across primary-grade levels. Mathematics Education Research Journal, 31, 349-365. https://doi.org/10.1007/s13394-019-00257-2

Livstrom, I. C., Szostkowski, A. H., \& Roehrig, G. H. (2019). Integrated STEM in practice: Learning from Montessori philosophies and practices. School Science and Mathematics, 119(4), 190-202. https://doi.org/10.1111/ssm.12331

Lopata, C., Wallace, N. V. \& Finn, K. V. (2005). Comparison of academic achievement between Montessori and traditional education programs. Journal of Research in Childhood Education, 20(1), 5-13. https://doi.org/10.1080/02568540509594546

Manouchehri, A., \& Goodman, T. (1998). Mathematics curriculum reform and teachers: Understanding the connections. The Journal of Educational Research, 92(1), 27-41. https://doi.org/10.1080/00220679809597573

Manouchehri, A., \& Sipes, C. (1998). Transforming middle school mathematics through teacher empowerment. In L. Leutzinger, (Ed.), Mathematics in the Middle (pp. 35-40). National Council of Teachers of Mathematics, Reston, VA.

Mapolelo, D. C. \& Akinsola, M. K. (2015). Preparation of mathematics teachers: Lessons from review of literature on teachers' knowledge, beliefs, and teacher education. American Journal of Educational Research, 3(4), 505-513. https://doi.org/10.12691/education-3-4-18

Marshall, C. (2017). Montessori education: A review of the evidence base. Science of Learning, 2(11), 1-9. https://doi.org/10.1038/s41539-017-0012-7

Merriam, S. B. (1998). Qualitative research and case study applications in education (2 ${ }^{\text {nd }}$ ed.). Jossey-Bass.

Merriam, S. B. (2009). Qualitative research: A guide to design and implementation (2nd ed.). Jossey-Bass. 
Mix, K. S., Smith, L. B., Stockton, J., Cheng, Y., \& Barterian, J. A. (2017). Grounding the symbols for place value: Evidence from training and long-term exposure to base-10 models. Journal of Cognition and Development, 18(1), $129-151$. https://doi.org/10.1080/15248372.2016.1180296

Monroe, E. E. (1984). The development of a mathematics methods course from pre-service elementary teachers: Some considerations. Technical Report. Western Kentucky University. https://files.eric.ed.gov/fulltext/ED244813.pdf

Murano, D., Sawyer, J. E., \& Lipnevich, A. A. (2020). A meta-analytic review of preschool social and emotional learning interventions. Review of Educational Research, 90(2), 227-263. https://doi.org/10.3102\%2F0034654320914743

Namukasa, I. K. (2016). Teaching practices in the Montessori system. In Proceedings of the $13^{\text {th }}$ International Congress on Mathematics education, ICME-13, Hamburg, Germany.

Namukasa, I. K. (2016, January). Mathematics for teachers in the Montessori system [Paper presentation]. The Fields Mathematics Institute, Toronto Ontario.

NCTM (2012). Council of the accreditation of educator preparation (CAEP) standards for Mathematics Teacher Preparations. NCTM. Retrieved November 5, 2019, from http://caepnet.org/accreditation/caep-accreditation/spa-standards-and-reportforms/nctm

Nisbet J., \& Watt, J. (1994). Case study. In J. Bell, T. Bush, A. Fox, J. Goodey, \& S. Goulding (Eds.), Conducting small-scale investigations in educational management (pp. 79-92). Harper \& Row. Oxford University.

Patton, M. Q. (2002). Qualitative research \& evaluation methods ( $3^{\text {rd }}$ ed.). Sage.

Peng, H.-H., \& Md-Yunus, S. (2014). Do children in Montessori schools perform better in the achievement test? A Taiwanese perspective. International Journal of Early Childhood, 46(2), 299-311. https://doi.org/10.1007/s13158-014-0108-7

Plake, B. S., \& Parker, C. S. (1982). The development and validation of a revised version of the Mathematics Anxiety Rating Scale. Educational and Psychological Measurement, 42(2), 551-557. https://doi.org/10.1177/001316448204200218

Ponte, J. P., \& Chapman, O. (2006). Mathematics teachers' knowledge and practices. In A. Gutierrez, \& P. Boero (Eds.), Handbook of research on the psychology of mathematics education: Past, present and future (pp. 461-494). Sense. https://doi.org/10.1163/9789087901127_017

Price, J. N., \& Ball, D. L. (1997). There's always another Agenda: Marshalling resources for mathematics reform. Journal of Curriculum Studies, 29(6), 637-666. https://doi.org/10.1080/002202797183810

Raimondo, R. (2018). Cosmic education in Maria Montessori: Arts and sciences as resources for human development. Studi sulla Formazione, 21, 249-260.

Rathunde, K., \& Csikszentmihalyi, M. (2005). Middle school students' motivation and quality of experience: A comparison of Montessori and traditional school environments. American Journal of Education, 111(3), 341. https://doi.org/10.1086/428885

Robson, C. (2002). Real world research (2 ${ }^{\text {nd }}$ ed.). Blackwell. https://doi.org/10.1016/S0262-1762(02)80276-0

Rosanova, M. J. (2003). Montessori elementary is different: What children study, what children do. Montessori Life, 15(2), 8-10.

Ross, J. A., McDougall, D., \& Hogaboam-Gray, A. (2002). Research on reform in mathematics education, 1993-2000. Alberta Journal of Educational Research, 48(2), 122-138.

Ross, S., (2012). The Montessori method: The development of a healthy pattern of desire in early childhood. Journal of Violence, Mimesis, and Culture, 19(1), 87-122. https://doi.org/10.1353/ctn.2012.0004

Rule, A. C., \& Stewart, R. A. (2002). Effects of practical life materials on kindergarteners' fine motor skills. Early Childhood Education Journal, 30(1), 9-13. https://doi.org/10.1023/A:1016533729704

Ryniker, D. H., \& Shoho, A. R. (2001). Student perceptions of their elementary classrooms: Montessori vs. traditional environments. Montessori Life, 13(1), 45-48.

Saracho, O., \& Spodek, B. (2009). Educating the young mathematician: A historical perspective through the nineteenth century. Early Childhood Education Journal, 36, 297-303. https://doi.org/10.1007/s10643-008-0293-9

Schneider, C. (2012). 5 Characteristics connecting Montessori education and the digital learning movement. Learning, Online and Blended. Retrieved January 9, 2020 from https://www.gettingsmart.com/2012/05/5-characteristics-connecting-montessoried-the-digital-learning-movement/

Sewornoo, S. (2016). Assessment literacy of mathematics teachers and challenges in the implementation of the school-based assessment in senior high schools of Ghana (Unpublished PhD Dissertation). University of Education.

Shiraz, M., \& Qaiser, S. (2017). Mathematics teachers' beliefs and their practices towards collaborative learning in public and private schools: A comparative case study. Journal of Educational Research, 20(2), 95-112. Retrieved August 29,2019, from http://jer.iub.edu.pk/journals/JER-Vol-20.No-2/Complete_file_of_JER_20_(2).pdf

Sztajn, P. (1995). Mathematics reform: Looking for insights from nineteenth century events. School scince and Mathematics, 95(7), 377-383. https://doi.org/10.1111/j.1949-8594.1995.tb15805.x

Tatto, M. T. (2013). The teacher education and development study in mathematics (TEDS-M): policy, practice, and readiness to teach primary and secondary mathematics in 17 countries. Technical Report. Amsterdam: International Association for the Evaluation of Student Achievement. 
Tatto, M. T., \& Senk, S. (2011). The mathematics education of future primary and secondary teachers: Methods and findings from the teacher education and development study in mathematics. Journal of Teacher Education, 62(2), $121-137$. https://doi.org/10.1177/0022487110391807

Thayer-Bacon, B. (2012). Maria Montessori, John Dewey, and William H. Kilpatrick. Education and Culture, 28(1), 3-20. https://doi.org/10.1353/eac.2012.0001

Toran, M. (2011). Montessori yönteminin çocukların kavram edinimi, sosyal uyumları ve küçük kas motor becerileri üzerindeki etkisinin incelenmesi [Investigation of the effect of the Montessori method on children's concept acquisition, social adaptation and small muscle motor skills] (Unpublished doctoral dissertation). Gazi University, Institute of Education Sciences, Ankara, Turkey.

Wang, T., \& Tang, S. (2013). Profiles of opportunities to learn for TEDS-M future secondary mathematics teachers. International Journal of Science and Mathematics Education, 11(4), 847-877. https://doi.org/10.1007/s10763-013-9421-0

White, A. L., Way, J., Perry, B., Southwell, B. (2006). Mathematical attitudes, beliefs, and achievement in primary pre-service mathematics teacher education. Mathematics Teacher Education and Development, 7, 33-52.

Whitescarver, K., \& Cossentino, J. (2008). Montessori and the mainstream: A century of reform on the margins. Teachers College Record, 110, 2571-2600. 


\section{APPENDIX}

\section{Data Collection Instruments}

The questionnaire: The questionnaire focused on beliefs (about mathematics - Factor 1, learning mathematics - Factor 2 , teaching mathematics - Factor 3; 55 questions in total), mathematics anxiety (Factor 4; 17 questions), and mathematics evaluation anxiety (Factor 5; 8 questions), and teaching practices (Factor 6; 15 questions). Many of the questions were adopted from the literature (e.g., Plake \& Parker, 1982; White, Way, Perry, \& Southwell, 2006). The short form, designed by the researchers, had identical factors with the long form: Instead of asking several questions on a factor, on the short form one question prompt was used for a participant to mark on a linear scale the extent of their belief on a factor. One side of the scale was more aligned to mathematics reform describing mathematics as experiential (rather than, platonic), knowledge is constructed (rather than, internalized), the teacher facilitates learning (rather than, tells), and comfort levels (rather than, anxiety) in mathematics. The questions on the factor on teacher practices were, on a rank order scale, and identical on both the long and short form: The short form, interviews, and observation templates were designed by the researchers.

The interview: The interview included 10 questions on: teacher training, socialization, practice, professional development, knowledge characteristics and belief characteristics, supports, learning materials resources, learners, assessment and follow-up questions from the survey. Follow-up questions from the survey were designed to deepen understanding of the survey results of individual participants, such as what they meant when they indicated a neutral stance on a question or when they added an elaboration. The observation template consisted of task design, teaching activities, knowledge and beliefs in action, and an entry for recording questions for follow-up interview. During the interviews and classroom observations teachers provided copies of their teaching curriculum, syllabus, resources and activities to the researchers.

The focus group: Researchers presented preliminary findings from the data, collected feedback as a form of member check with participants who consented to participate in the focus group. The interviews, observations and discussions were audio recorded, with a few interviews and observations recorded on video upon teacher agreement. 